\title{
A portrait of American farmers
}

Book review by Kathlee Freeman*

University of Missouri-Columbia

\section{Review of The Color of Food: Stories of Race, Resilience and Farming, by Natasha Bowens. (2013). Gabriola Island, British Columbia, Canada: New Society Publishers. Available as paperback and ebook; 240 pages. Publisher's website: http://www.newsociety.com/Books/C/The-Color-of-Food}

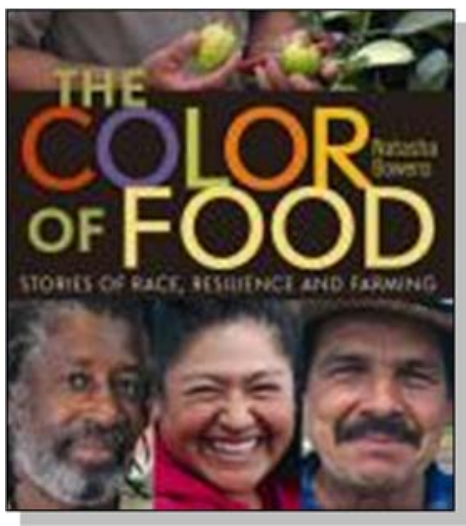

Submitted March 30, 2015 / Published online July 20, 2015

Citation: Freeman, K. (2015). A portrait of American farmers [Book review]. Journal of Agriculture, Food Systems, and Community Development, 5(4), 195-197. http://dx.doi.org/10.5304/jafscd.2015.054.003

Copyright (C) 2015 by New Leaf Associates, Inc.

$\mathrm{T}$ here is an agricultural renaissance of sorts taking place that can be seen in the rising sales of organic food, the sprouting of urban gardens throughout major cities, and the growing legion of locavores. While this surge of interest in what we eat and where it comes from is good for our health and communities, criticism that alternative food systems are elitist and inaccessible has tinged conversations around the growing good-food

* Kathlee Freeman, Rural Sociology Department, University of Missouri-Columbia; 121 Gentry Hall; Columbia, Missouri 65211 USA; +1-573-882-7451; kaf4z7@mail.missouri.edu

Kathlee Freeman is a master's candidate at the University of Missouri-Columbia in rural sociology while also working toward a graduate certificate in geographic information science. Her research focus includes the role of technology use in market access for smallholder farmers in east Africa. She is an advisory board member to the Women, Food and Agriculture Network and a contributing writer to Food Tank: The Food Think. Tank (http://foodtank.com). movement. Indeed, all too often the story of this movement is told only through white voices.

Natasha Bowens' The Color of Food provides a window through which we can see a fuller picture of agriculture in the United States. The reader accompanies Bowens as she crisscrosses the country, revealing the many farmers and communities of color dedicated to their land, food sovereignty, and way of life. The book is a product of Bowens' travels across 15,000 miles $(24,140 \mathrm{~km})$ and 16 states to interview farmers of color and to unpack the often complicated emotions related to land ownership, farming, and the exploitation and oppression that has frequently been linked to agriculture.

Bowens introduces her subject matter by first telling her own story. Working as a political organizer and blogger in Washington, D.C., she became enamored with food and agriculture. Immersing herself in the alternative food movement, she participated in everything from attending 
conferences to volunteering at community gardens, before eventually quitting her job in order to work on an organic farm. Bowens describes herself as a woman of color, deeply connected to the earth and farming, but nevertheless conflicted. She explains in her introduction, "As I began to feel rooted in my life as someone who worked the land, I quickly realized all the cultural and historical baggage that came with that" (p. VIII). She also noticed that there was a striking lack of people of color working alongside her at the organic farm. She asks wryly, "Why am I the only brown person here?" (p. 2).

With support from her community, Bowens raised the funds to embark on an ambitious project to uncover and tell the full story that occurs at the intersection of agriculture and communities of color. The result is 25 "portraits" of individual farmers whose stories are told through both words and photographs. The photos shaped the project in a way that would not have been possible without them. Bowens took about 3,500 photographs along her travels, and places photos at the start of each "portrait" and throughout the text. The importance of these photos lies in their ability to capture a snippet of life and provide a brief glimpse into the moments shared between Bowens and the interviewees. Photos like those of Nelida Martinez, migrant worker turned landowner, tending a vined plant, or Yasin Muhaimin, schoolteacher turned farmer, preparing a chicken for slaughter, tell a larger story that words alone would not be able to capture.

I read Bowens' book in an afternoon, but over the course of several weeks I revisited many of the stories. Common threads of experiences linked these diverse farmers, weaving together one coherent story made up of many voices. The importance of land ownership and stewardship radiated from the pages. Reading the quotations, you could imagine chests puffed with pride as each of these farmers gave a tour of their family farm or land purchased after years of saving. The theme of independence bubbles up from each story, and a sense of respect, for both the land and the farming profession, permeates the language of each farmer. For them this is not a job, but a calling.

Each interview tells a story of triumph; the word empowerment immediately comes to mind as
I recall the interviews. Black southern farmers spoke of land that had been wrestled from the vicious cycle of sharecropping. Immigrants spoke of working for someone else until they were able to purchase their own land and achieve the often elusive American Dream. Indigenous farmers spoke of recapturing aspects of their culture that had been stolen through forced resettlements and assimilation.

However, despite idyllic scenes of vegetable rows and well-tended herds of animals, Bowens and the farmers she interviews tell a second story that runs parallel to the first. This second story explains the injustices, both past and present, that have created breaks between the land, people of color, and their sovereignty, over both food and life choices. It also tells the story of protest, liberation, and overcoming adversity. The fight to return to a slower way of growing our food and support of small-scale farming operations has been fought by these farmers of color long before the terms "organic" or "permaculture" made their way into our cultural lexicon.

This is all the more important given the well documented problems brewing within the agricultural sector. Farmers in the U.S. are getting older, with the average age edging toward 60, and fewer younger people are looking to farming as a viable career path. The agricultural landscape looks much different from a few generations ago, and many small to medium-sized farmers are looking for ways to remain viable. The farmers profiled in The Color of Food have learned how to make their operations profitable, against all odds. Many have overcome discriminatory lending practices, the difficulty of accessing funds for startup costs, forced removal from their rightful land, language barriers, and, for those returning to the land, the loss of knowledge of how to farm. As a result, their stories are the ideal lens through which to envision a revitalization of the family farm in general.

The Color of Food challenges those of us who advocate for a better food system to be truly inclusive and to incorporate the full spectrum of experiences into our understanding of what a just food system looks like. For activists and policymakers, this book provides tangible examples of the problems that small-scale farmers face. For 
students and teachers, the rich history, and often untold story, of agriculture in the U.S. told by these farmers provides a deeper level of historical and cultural understanding. As Rigoberto Delgado, with the National Immigrant Farming Initiative, explains, "For those of us that care about community food security, family farmers and social justice, we have a tremendous opportunity right now to support these farmers" (p. 56). These opportunities include linking farmers of color with business and legal resources, supporting policies and programs that will give minority farmers financial assistance, and, of course, purchasing locally grown food. 